\title{
Evaluation of Urinary Hepcidin as a Marker for the Early Diagnosis of Iron Deficiency Anemia in Children
}

\author{
Somaia Moussa', Asmaa Abd-Alwakeel Ibrahim², Nora Mohamed Ahmed ${ }^{3}$ \\ ${ }^{1}$ El-Mansura, Ad Daqahliyah, Egypt \\ ${ }^{2}$ Pediatrics, Faculty of Medicine for Girls, Al-Azhar University, Al Behira, Egypt \\ ${ }^{3}$ Biochemistry, Faculty of Medicine for Girls, Al-Azhar University, Cairo, Egypt \\ Email:moaaz2009@gmail.com, asmaawakeel@yahoo.com,noraseliem30@gmail.com
}

How to cite this paper: Moussa, S., Ibrahim, A.A.-A. and Ahmed, N.M. (2020) Evaluation of Urinary Hepcidin as a Marker for the Early Diagnosis of Iron Deficiency Anemia in Children. Open Journal of Pediatrics, 10, 347-355.

https://doi.org/10.4236/ojped.2020.102035

Received: June 1, 2020

Accepted: June 26, 2020

Published: June 29, 2020

Copyright $\odot 2020$ by author(s) and Scientific Research Publishing Inc. This work is licensed under the Creative Commons Attribution International License (CC BY 4.0).

http://creativecommons.org/licenses/by/4.0/

\begin{abstract}
Background: Iron deficiency is an essential element, because nearly all living organism urine hepcidin levels could potentially be used in the determination of iron requirements and be an accurate indicator of physiological IDA. Aim: The present study aimed to evaluate the role of urinary hepcidin as an early diagnostic marker of iron deficiency anemia in children. Methods: This study included 45 children. Their age ranged from 6 to 16 years with hemoglobin levels $\leq 11.5 \mathrm{gm} / \mathrm{dL}$ and ferritin levels $\leq 20 \mathrm{ng} / \mathrm{mL}$. The diagnostic performance of urinary hepcidin was estimated by analyzing the receiver operating characteristic curve. Diagnostic cut-off point with a high predictive value for iron deficiency was selected. Results: This study showed no statistically significant difference between the two studied groups regarding to demographic data. There were decrease in serum iron, ferritin, hemoglobin and Red blood cells (RBCs) indices in patient than the control group. There was non-significant decrease in urinary hepcidin in the study group compared to control group. The sensitivity and specificity of urinary hepcidin in diagnoses of iron deficiency anemia was 57.8 and 62.2 respectively with positive predictive value (63.3) in our study. There was positive correlation between urinary hepcidin and mean corpuscular volume (MCV), $(\mathrm{r}=0.221),(\mathrm{p}=0.036)$, with the cut of value < 63.33. Conclusion: We concluded that the decrease of urinary level of hepcidin was non-significant in iron deficiency anemia compare to control group and needed further researches.
\end{abstract}

\section{Keywords}

Hepcidin, Iron, Anemia, Pediatrics 


\section{Introduction}

Iron is an essential element for nearly all living organisms. Iron is a key component of oxygen storage and transporting proteins, such as hemoglobin and myoglobin, as well as many enzymes that catalyze oxidation-reduction reactions necessary to generate energy and produce various metabolic intermediates for host defense [1]. Ferritin has been used as an indicator of iron stores but its levels are also elevated in patients with coexisting inflammation. Soluble transferring receptor (STFR) levels are seen to reflect tissue iron deficiency, but they are also influenced by erythropoietin activity. In addition, transferrin saturation levels may be affected by inflammation and undergo diurnal variation [2].

Hepcidin-25, a 25-amino acid peptide hormone produced in the liver is a central regulator of systemic iron metabolism [3]. Hepcidin levels are reduced in patients with iron deficiency anemia (IDA). Therefore, blood or urine hepcidin levels could potentially be used in the determination of iron requirements and be an accurate indicator of IDA [4].

The aim of this study was to evaluate the role of urinary hepcidin as an early diagnostic marker of iron deficiency anemia in children.

\section{Patients and Methods}

This was a case control comparative study carried out in the outpatient clinics of general hospital in AL-Dakahlia governorate from $24^{\text {th }}$ February 2019 to $2^{\text {nd }} J a n$ uary 2020, included 45 children, their age ranged from 6 to 16 years and with hemoglobin levels $\leq 11.5 \mathrm{gm} / \mathrm{dL}$ and ferritin levels $\leq 20 \mathrm{ng} / \mathrm{mL}$ [5], 45 healthy children age and sex matched were included as a control group and were exclude conditions that might affect serum ferritin as (acute infection and acute inflammation), patients suffering from chronic diseases or chronic infection, other forms of nutritional deficiency anemia (e.g. folic acid, B12), any form of hemolytic anemia and children who received iron therapy or blood transfusion the 3 months prior to the study.

Approach of the ethical committee of Al-Azhar faculty of medicine. A written informed consent was taken from all participant after proper explanation of the study, the steps of the study, the aim, the potential benefits and hazards, all were discussed with the parents of the studied groups. The included children groups had the right to withdraw from the study at any time without giving any reasons.

All children subjected to detailed medical history (personal, family, past history and history of present illness), general examination, abdominal examination and anthropometric measurements were done for all children (patients, control)

\subsection{Laboratory Investigation}

$4 \mathrm{ml}$ blood was withdrawn, $2 \mathrm{ml}$ was collected on EDTA tube for complete blood count that were done immediately, $2 \mathrm{ml}$ was collected in tube and centrifuged for serum iron and ferritin, early morning urinary sample was collected in sterile bottle and preserved in refreg $\left(-20^{\circ} \mathrm{C}\right)$ till the time of assay, estimation of uri- 
nary hepcidin by ELISA as assays were carried out in urine by a sandwich enzyme-linked immunosorbent assay (ELISA) technique using reagents provided by SinoGeneclon Co. Ltd., mindray MR-96A. The theoretical sensitivity or the minimum detectable dose (MDD) of urinary hepcidin ranged from $7.5 \mu \mathrm{g} / \mathrm{L}$ to 150 $\mu \mathrm{g} / \mathrm{L}$. The mean MDD was $1.2 \mu \mathrm{g} / \mathrm{L}$ (Catalog No: SG-10182, Human hepcidin kit).

\subsection{Statistical Analysis}

The collected data were coded and verified prior to data entry; all statistical analysis was carried out using the statistical package for Social Sciences (SPSS/Windows version 17.0.0. SPSS Inc., an IBM Company), Microsoft excel was used for drawing figures. 1) Descriptive statistics: Contains variables were presented as mean \pm SD (standard deviation) or number (percentage) as appropriate. 2) Analytical statistics: statistical analysis was carried out using the Student $(\mathrm{t})$ test, and $\mathrm{P}$ value $(\mathrm{P}<0.05)$ was considered as a significant, $\mathrm{P}$ value $(>0.05)$ was no-significant and $\mathrm{P}$ value $(<0.001)$ was highly significant.

\subsection{Ethical Considerations}

This study was discussed with the children and their parents. A written informed consent was taken after an explanation of the study to them and before the initiation of the research study: An informed written consent was obtained from all parents' patients and control groups before getting them involved in the study, Approach of the ethical committee of Al-Azhar faculty of medicine, The steps of the study, the aim, the potential benefits and hazards, all were discussed with the parents of the studied groups, Confidentially of all data were ensured, The patients and the control groups had the right to withdraw from the study at any time without giving any reasons.

\section{Results}

Table 1 shows no significant difference between the studied groups regarding to age and sex, there was significant decrease in mean of hemoglobin concentration $(\mathrm{Hb}), \mathrm{RBCs}$ indices and serum iron, ferritin in patients group compared to control group.

Non-significant decrease in urinary hepcidin in patient group compared to the control.

Table 2 Correlation study between urinary hepcidin, other clinical and laboratory parameters was conducted in the whole study population and showed positive correlation between urinary hepcidin and MCV.

Figure 1 The ROC curve showed Sensitivity and specificity of urinary hepcidin in diagnoses of iron deficiency anemia that was 57.8 and 62.2 respectively with positive predictive value.

\section{Discussion}

This study included forty-five patients with iron deficiency anemia with age 
range from 6 to 16 years and forty-five healthy children with matched age and sex. As regard to demographic data of studied cases, the mean of age of patients group was $8.78 \pm 1.54$, however for control group was $9.31 \pm 1.54$ years with no significant difference between the two groups. Regarding gender, the results were presented as males were 21 cases represented (46.7\%) in patients group and 28 cases $(62.2 \%)$ in control group; However, females were 24 cases $(53.3 \%)$ in patients group and 17 cases $(37.8 \%)$ in control group with no significant difference between the two groups.

Table 1. Comparison between patient and control groups regarding demographic data, clinical and laboratory data.

\begin{tabular}{|c|c|c|c|}
\hline \multirow[b]{2}{*}{ Parameter } & \multicolumn{2}{|c|}{ Groups } & \multirow[b]{2}{*}{ Test of Significance } \\
\hline & $\begin{array}{l}\text { Patients Group } \\
\quad \mathrm{N}=45\end{array}$ & $\begin{array}{l}\text { Control Group } \\
\qquad N=45\end{array}$ & \\
\hline Age (year) & $8.78 \pm 1.54$ & $9.31 \pm 1.54$ & $\begin{array}{l}t=1.642 \\
P=0.103\end{array}$ \\
\hline Male Female & $21(46.7 \%)$ & $21(46.7 \%)$ & $\mathrm{X}^{2}=2.195$ \\
\hline & $24(53.3 \%)$ & $24(53.3 \%)$ & $\mathrm{P}=1.38$ \\
\hline Weight z score (Kg) & $-0.25 \pm 1.22$ & $-0.19 \pm 0.82$ & $\begin{array}{l}\mathrm{t}=2.014 \\
\mathrm{P}=0.044\end{array}$ \\
\hline Height $\mathrm{z}$ score $(\mathrm{cm})$ & $-0.19 \pm 0.98$ & $-0.11 \pm 0.99$ & $\begin{array}{l}\mathrm{t}=1.461 \\
\mathrm{P}=0.148\end{array}$ \\
\hline Serum iron $(\mathrm{mcg} / \mathrm{dl})$ & $47.9(20-89.1)$ & $64(36-87)$ & $\begin{array}{l}\mathrm{z}=-3.209 \\
\mathrm{P}=0.001^{\star *}\end{array}$ \\
\hline Serum Ferritin (ng/ml) & $37.15(4-77.8)$ & $46(28-78)$ & $\begin{array}{l}\mathrm{z}=-2.787 \\
\mathrm{P}=0.005^{\star}\end{array}$ \\
\hline Hemoglobin ( $\mathrm{g} / \mathrm{dl})$ & $9.76 \pm 0.84$ & $12.27 \pm 0.58$ & $\begin{array}{l}t=-16.587 \\
P<0.001^{* *}\end{array}$ \\
\hline $\operatorname{RBCs}\left(10^{6} / \mu \mathrm{l}\right)$ & $4.03 \pm 0.60$ & $4.91 \pm 0.58$ & $\begin{array}{l}\mathrm{t}=-7.110 \\
\mathrm{P}<0.001^{* *}\end{array}$ \\
\hline $\mathrm{MCV}(\mathrm{FI})$ & $70.06 \pm 5.86$ & $82.55 \pm 4.95$ & $\begin{array}{l}\mathrm{t}=-10.927 \\
\mathrm{P}<0.001^{* *}\end{array}$ \\
\hline $\mathrm{MCH}$ (p.g) & $22.31 \pm 2.36$ & $29.05 \pm 8.31$ & $\begin{array}{l}\mathrm{t}=-5.233 \\
\mathrm{P}<0.001^{* *}\end{array}$ \\
\hline $\mathrm{MCHC}(\mathrm{g} / \mathrm{dl})$ & $31.88 \pm 1.69$ & $32.49 \pm 1.06$ & $\begin{array}{l}\mathrm{t}=-2.075 \\
\mathrm{P}=0.041^{\star}\end{array}$ \\
\hline $\operatorname{PLTs}\left(10^{3} / \mu \mathrm{l}\right)$ & $255(82-482)$ & $234(145-442)$ & $\begin{array}{c}\mathrm{z}=-1.283 \\
\mathrm{P}=0.199\end{array}$ \\
\hline Urinary Hepcidin (ng/ml) & $\begin{array}{c}50.65 \\
(26.53-126.95)\end{array}$ & $\begin{array}{c}71.93 \\
(25.49-132.92)\end{array}$ & $\begin{array}{c}z=-1.969 \\
P=0.058\end{array}$ \\
\hline
\end{tabular}

${ }^{\star}$ Significant $(\mathrm{P}<0.05) ;{ }^{* \star}$ Highly Significant $(\mathrm{P}<0.001)$. 
Table 2. Correlation study between urinary hepcidin, other clinical and laboratory parameters in the whole study population.

\begin{tabular}{ccc}
\hline & \multicolumn{2}{c}{ URINARY HEPCIDIN } \\
\cline { 2 - 3 } Parameter & $\mathrm{r}$ & $\mathrm{p}$ \\
\hline Age (year) & 0.037 & 0.730 \\
Height $(\mathrm{cm})$ & -0.054 & 0.613 \\
Weight $(\mathrm{kg})$ & -0.089 & 0.407 \\
Serum Iron $(\mathrm{mcg} / \mathrm{dl})$ & -0.044 & 0.683 \\
Serum Ferritin (ng/ml) & 0.011 & 0.918 \\
Hemoglobin (g/dl) & 0.136 & 0.201 \\
RBCs $(106 / \mu \mathrm{l})$ & 0.184 & 0.082 \\
MCV (FI) & 0.221 & $0.036^{*}$ \\
MCH (p.g) & 0.185 & 0.081 \\
MCHC (g/dl) & 0.058 & 0.589 \\
PLTs $(103 / \mu \mathrm{l})$ & 10.091 & 0.339
\end{tabular}

*Significant $(\mathrm{P}<0.05)$; ${ }^{*}$ Highly Significant $(\mathrm{P}<0.001)$.

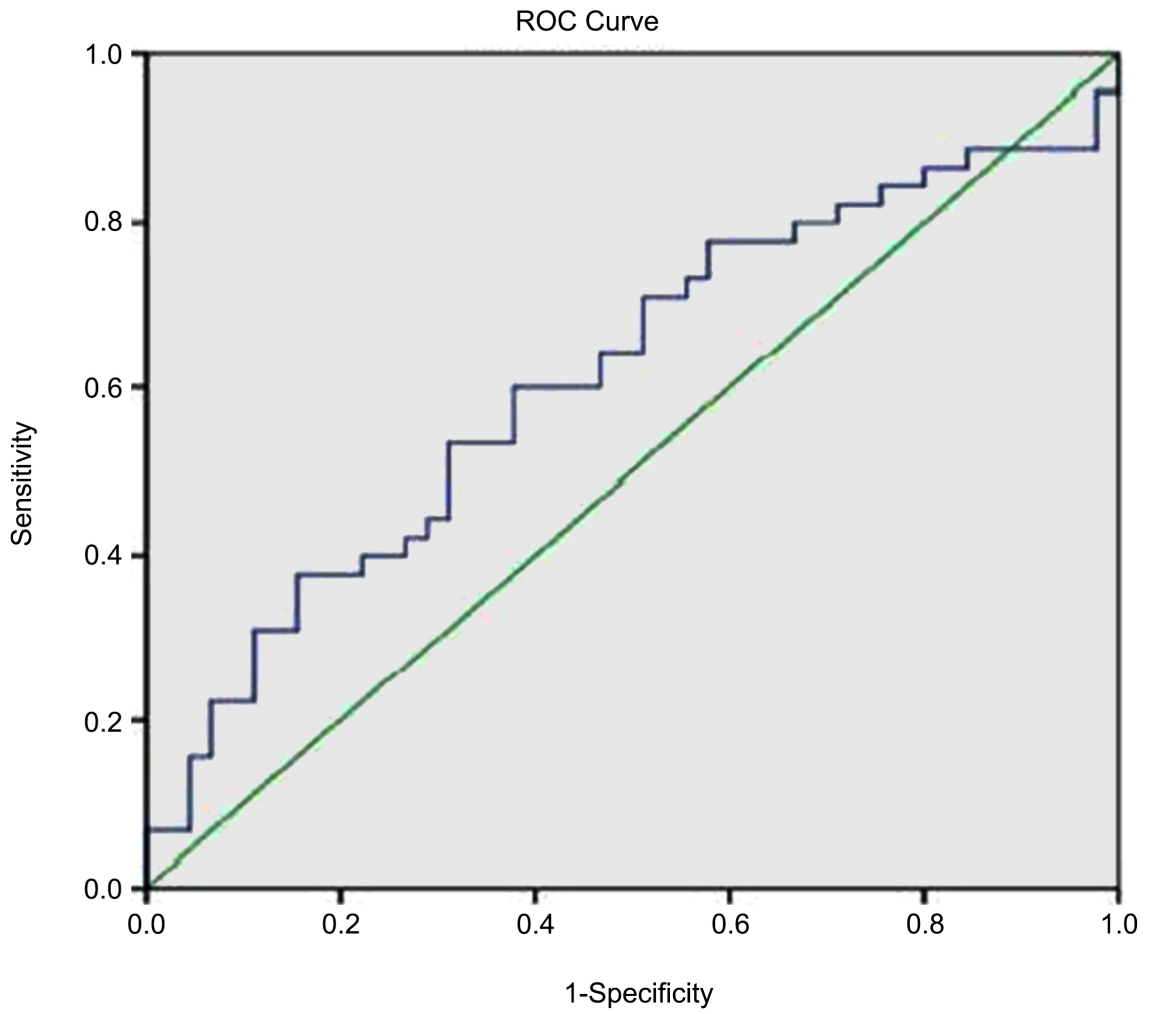

Figure 1. ROC Curve of urinary hepcidin in diagnosis of iron deficiency anemia. 
The mean hemoglobin concentration, mean corpuscular volume, mean corpuscular Hemoglobin, red blood cells of the studied patients were significantly lower than those of the controls $(\mathrm{P}>0.01)$ for each except mean corpuscular hemoglobin concentration $(\mathrm{P}=0.041)$. The same results were obtained by Sanad and Gharib, Koch et al. and Elsayed [6] [7] [8].

Sanad and Gharib (2011), Przybyszewska et al. (2013) and Mupfudze (2014) [6] [9] [10] reported that $\mathrm{MCV}, \mathrm{MCH}$ and $\mathrm{MCHC}$ were decreased significantly with the presence of iron deficiency anemia and this may be due that iron deficiency anemia is one of the microcytic anemia's in which MCV $>70$ (fl/red cell) causing small red blood cells.

Lolascon (2009) and Sanghvi et al. (2010) [11] [12] stated that Iron deficiency anemia (IDA) is defined as a disease of the reduced erythrocyte production with low content of hemoglobin, resulting in red blood cells that are abnormally small (microcytic) and contain a decreased amount of hemoglobin (Hypochromic).

The means serum iron and serum ferritin levels of the studied patients were significantly lower than those of the controls with $(\mathrm{P}$ value $=0.001)$ for serum iron and $(\mathrm{P}=0.005)$ for serum ferritin. The same results were obtained by (Sanghvi 2010), (Sanad and Gharib 2011), (Elsounesy, 2015), (Rasheed et al., 2013), and (Elsayed, 2017) [6] [8] [12] [13], who study the relation between iron concentration and anemia and they found that the major cause of anemia is the poverty of iron.

We observed decrease in urinary hepcidin but with no significant value while the studies done by (Cherian et al., 2008), (Sanad and Gharib, 2011), (Al-Mazahi et al. 2015), and (Elsayed, 2017) [6] [8] [14] [15] found that urinary hepcidin levels were significantly lower in iron deficiency anemia (IDA), (Ganz et al., 2008) [16], stated that hepcidin is homeostatically regulated by iron and erythropoietic activity and suppressed in ID, allowing increase of absorption of dietary iron and replenishment of iron stores. The feedback loop between iron and hepcidin ensures stability of plasma iron concentrations [17], hepcidin production is also regulated the process which consumes most iron erythropoiesis [18], and our findings could be attributed to the small number of the included children.

Increased erythropoietic activity suppresses hepcidin production which allows the release of stored iron from macrophages and hepatocytes, and increased iron absorption, all resulting greater supply of iron for hemoglobin synthesis [19].

In the present study, hepcidin level had no correlation with age, and these findings were similar to the finding observed by (Cherian et al., 2008) [14] who found that there were no significant correlation between urinary hepcidin and age. Our study also revealed an insignificant correlation between hemoglobin level and urinary hepcidin concentration (P value $=0.201$ ). These results were in line with those of (Schulze et al., 2008) [20] who characterized the role of hepcidin in anemia and found no correlation between $\mathrm{Hb}$ level, and urinary hepcidin concentration, while our results were in contrary with those of (Choi et al., 2012) and (A El-Kelany et al., 2019) [21] [22] who detected the urinary hepcidin level 
asan early prediction of iron deficiency and found that there was significant positive correlation between $\mathrm{Hb}$ level and urinary hepcidin concentration.

The present study also revealed a significant positive correlation between urinary hepcidin and mean corpuscular volume $(\mathrm{MCV}),(\mathrm{P}$ value $=0.036)$, and there was no correlation between hepcidin and MCHC $(P=0.589)$, there were no correlation between urinary hepcidin and $\mathrm{MCH}$.

In agreement with our study, the study done by (Mohamed et al., 2014) [23], to assess the correlation between hepcidin biochemical parameters and hematological indices among iron deficient anemic children aged (6 - 12) years in Gaza city, they found that there was no correlation between $\mathrm{MCH}$ and urinary hepcidin concentrations, and also did not agree with (Cherian et al., 2008) and (Duru et al., 2013) [14] [24] who detected the role of urinary hepcidin level in early prediction of iron deficiency in children and found that there was significant positive correlation between $\mathrm{MCH}$ and urinary hepcidin.

Our results showed no correlation between urinary hepcidin level and serum iron $(\mathrm{r}=0.044),(\mathrm{P}=0.689)$, these results agreed with (Mohamed et al., 2014) [23] who study the correlation between urinary hepcidin and hematological indices concentration among iron deficient anemic children and they found no correlation between urinary hepcidin and serum iron and this were in contrary with (Prentice et al., 2012) [25] who found significant positive correlation between hepcidin and serum iron. The results of the correlation between ferritin and urinary hepcidin showed no significance $(\mathrm{P}=0.918)$ and these results were in agreement with (Choi et al., 2012) [21] and (A El-Kelany et al., 2019) [22] who observed weak correlations between serum ferritin and hepcidin concentration, and in contrary with (Sanad and Gharib, 2011) [6] who found significant positive correlation between scrum ferritin and urinary hepcidin concentration.

Our result shows that no correlation between urinary hepcidin and weight, height of the IDA patient height $(\mathrm{P}=0.613)$; Weight $(\mathrm{P}=0.407)$, and there was no correlation between urinary hepcidin and platelets $(r=10.091),(P=0.339)$

The Sensitivity and specificity of urinary hepcidin in diagnoses of iron deficiency anemia was (57.8) and (62.2) respectively with positive predictive value (63.3) in our study and Positive correlation between urinary hepcidin and MCV.

\section{Conclusion}

We concluded that urinary hepcidin decreased in patients with iron deficiency anemia but did not reach a significant level.

\section{Recommendation}

We recommend further studies are needed to evaluate if it can be used as early marker in diagnoses of iron deficiency anemia.

\section{Conflicts of Interest}

The author declares no conflicts of interest regarding the publication of this paper. 


\section{References}

[1] Sigismond, L., Thomas, G. and Emmanuel, R. (2014) Iron Is Essential for Living. Critical Care (London, England), 18, Article No. 678. https://doi.org/10.1186/s13054-014-0678-7

[2] Axel, D., Karima, F. and Jürgen, S. (2018) Limitations of Serum Ferritin in Diagnosing Iron Deficiency in Inflammatory Conditions. International Journal of Chronic Disease, 2018, Article ID: 9394060. https://doi.org/10.1155/2018/9394060

[3] Musallam, K.M. and Taher, A.T. (2018) Iron Deficiency beyond Erythropoiesis: Should We Be Concerned? Current Medical Research and Opinion, 34, 81-93. https://doi.org/10.1080/03007995.2017.1394833

[4] De Franceschi, L., Iolascon, A., Taher, A. and Cappellini, M.D. (2017) Clinical Management of Iron Deficiency Anemia in Adults: Systemic Review on Advances in Diagnosis and Treatment. European Journal of Internal Medicine, 42, 16-23. https://doi.org/10.1016/j.ejim.2017.04.018

[5] Van Santen, S., van Dongen-Lases, E.C., de Vegt, F., et al. (2011) Hepcidin and Hemoglobin Content Parameters in the Diagnosis of Iron Deficiency in Rheumatoid Arthritis Patients with Anemia. Arthritis \& Rheumatism, 63, 3672-3680. https://doi.org/10.1002/art.30623

[6] Sanad, M. and Gharib, A.F. (2011) Urinary Hepcidin Level as Anearly Predictor of Iron Deficiency in Children: A Case Control Study. Italian Journal of Pediatrics, 37, Article No. 37. https://doi.org/10.1186/1824-7288-37-37

[7] Koch, T.A., Myers, J. and Goodnough, L.T. (2015) Intravenous Iron Therapy in Patients with Iron Deficiency Anemia: Dosing Considerations. Anemia, 2015, Article ID: 763576. https://doi.org/10.1155/2015/763576

[8] Elsayed, W. (2017) Iron Deficiency Anemia, Serum Iron in Children with Bronchial Asthma. Zagazig University Medical Journal, 23, 1-11. https://doi.org/10.21608/zumj.2017.4682

[9] Przybyszewska, J., Zekanowska, E., Kędziora-Kornatowska, K., Boinska, J., Cichon, R. and Porzych, K. (2013) Serum Prohepcidin and Other Iron Metabolism Parameters in Elderly Patients with Anemia of Chronic Disease and with Iron Deficiency Anemia. Polskie Archiwum Medycyny Wewnetrznej, 123, 105-111.

[10] Mupfudze, T.G. (2014) Plasma Concentrations of Hepcidin in Anemic Zimbabwean Infants. PLoS ONE, 10, e0135227. https://doi.org/10.1371/journal.pone.0135227

[11] Iolascon, A., Falco, L.D. and Beaumont, C. (2009) Molecular Basis of Inherited Microcytic Anemia Due to Defects in Iron Acquisition or Heme Synthesis. Haematologica, 94, 395-408. https://doi.org/10.3324/haematol.13619

[12] Sanghvi, T.G., Harvey, P.W. and Wainwright, E. (2010) Maternal Iron-Folic Acid Supplementation Programs: Evidence of Impact and Implementation. Food and Nutrition Bulletin, 31, S100-S107. https://doi.org/10.1177/15648265100312S202

[13] Rasheed, H., Mahgoub, D., Hegazy, R., et al. (2013) Serum Ferritin and Vitamin D in Female Hair Loss: Do They Play a Role? Skin Pharmacology and Physiology, 26, 101-107. https://doi.org/10.1159/000346698

[14] Cherian, S., Forbes, D.A., Cook, A.G., Sanfilippo, F.M., Kemna, E.H., Swinkels, D.W. and Burgner, D.P. (2008) An Insight into the Relationships between Hepcidin, Anemia, Infections and Inflammatory Cytokines in Pediatric Refugees: A Cross-Sectional Study. PLoS ONE, 3, e4030. https://doi.org/10.1371/journal.pone.0004030

[15] Al-Mazahi, M.M., Mekky, A.A., Mohamed, A.S. and Elfar, E.S. (2015) Urinary Hep- 
cidinin Diagnosis of Iron Deficiency Anemia. Asian Journal of Clinical Nutrition, 7, 9-16. https://doi.org/10.3923/ajcn.2015.9.16

[16] Ganz, T., Olbina, G., Girelli, D., Nemeth, E. and Westerman, M. (2008) Immunoassay for Human Serum Hepcidin. Blood, 112, 4292-4297. https://doi.org/10.1182/blood-2008-02-139915

[17] Nemeth, E. (2010) Targeting the Hepcidin-Ferroportin Axis in the Diagnosis and Treatment of Anemias. Advances in Hematology, 2010, Article ID: 750643. https://doi.org/10.1155/2010/750643

[18] Nicolas, G., Chauvet, C., Viatte, L., Danan, J.L., Bigard, X., Devaux, I., Beaumont, C., Kahn, A. and Vaulont, S. (2002) The Gene Encoding the Iron Regulatory Peptide Hepcidin Is Regulated by Anemia, Hypoxia, and Inflammation. Journal of Clinical Investigation, 110, 1037-1044. https://doi.org/10.1172/JCI0215686

[19] Pagani, A., Nai, A., Silvestri, L. and Camaschella, C. (2019) Hepcidin and Anemia: A Tight Relationship. Frontiers in Physiology, 10, 1294. https://doi.org/10.3389/fphys.2019.01294

[20] Schulze, K.J., Christian, P., Ruczinski, I., Ray, A.L., Nath, A., Wu, L.S.-F. and Semba, R.D. (2008) Hepcidin and Iron Status among Pregnant Women in Bangladesh. Asia Pacific Journal of Clinical Nutrition, 17, 451-456.

[21] Choi, H.S., Song, S.H., Lee, J.H., Kim, H.J. and Yang, H. (2012) Serum Hepcidin Levels and Iron Parameters in Children with Iron Deficiency. Korean Journal of Hematology, 47, 286-292. https://doi.org/10.5045/kjh.2012.47.4.286

[22] Al Sharkawy, S., El-Kelany, A.M., Anani, M.M. and El Sayed, H.E. (2019) Urinary Hepcidin Concentration in Assessment of Iron Homeostasis in Pediatrics. Egyptian Journal of Haematology, 44, 105-110.

[23] Mujib, A.S.M., Mahmud, A.S.M., Halde, M. and Hasan, C.M.M. (2014) Study of Hematological Parameters in Children Suffering from Iron Deficiency Anaemia in ChattagramMaa-o-Shishu General Hospital, Chittagong, Bangladesh. Anemia, 2014, Article ID: 503981. https://doi.org/10.1155/2014/503981

[24] Duru, N.S., Seval, H., Çivilibal, M., Koldaş, M. and Elevli, M. (2014) Serum Hepcidin, Iron Metabolism and Infection Parameters in Children with Anemia of Inflammation and with Iron Deficiency Anemia. Turkish Journal of Biochemistry, 39, 529-533. https://doi.org/10.5505/tjb.2014.19480

[25] Prentice, A.M., Doherty, C.P., Abrams, S.A., Cox, S.A., Atkinson, S.A., Verhoef, H., Armitag, A.E. and Drakesmith, H. (2012) Hepcidin Is the Major Predictor of Erythrocyte Iron Incorporation in Anemic African Children. Blood, 119, 1922-1928. https://doi.org/10.1182/blood-2011-11-391219 